\title{
Look Before You Leap: Some Cautionary Notes on Civic Republicanism
}

\author{
Michael A. Fitts $\dagger$
}

The dream of reason did not take power into account. ${ }^{1}$

Since the judicial retreat in the face of the New Deal revolution, constitutional scholars have generally viewed the "counter-majoritarian difficulty" as the central dilemma of constitutional theory. ${ }^{2}$ The academic response to this normative challenge has varied widely, with some scholars virtually raising the flag of judicial surrender, ${ }^{3}$ others discovering judicial authority in perfecting legislative democracy, ${ }^{4}$ and still others recognizing a democratic legitimacy in the judiciary itself. ${ }^{5}$

"Modern civic republicanism" approaches questions of judicial review from a different perspective. Rather than urging the courts to further pure democratic rule, which is criticized for its lack of intellectual coherence and normative appeal, modern civic republicans articulate an alternative vision of public decisionmaking-a model of policymaking in which decisions are made in the legislative process through principled deliberation and reasoned dialogue. Regardless of one's views on these issues, the importance of this alternative perspective, and Cass Sunstein's powerful contributions to it, cannot be denied. By sketching a full vision of legislative decisionmaking through reasoned deliberation, civic republicanism seeks to redirect the focus of constitutional theory itself. This vision, moreover,

$†$ Assistant Professor of Law, University of Pennsylvania. Many of the themes discussed in this comment, which are treated cursorily here due to page limitations, are explored at greater length in Fitts, The Vices of Virtue: A Political Party Perspective on Civic Virtue Reforms of the Legislative Process, 136 U. PA. L. REv. 1567 (1988). I reiterate here my thanks to the various colleagues and friends who commented on that earlier piece.

1. P. Stark, The Social Transformation of american Medicine 3 (1981).

2. See, e.g., A. Bickel, The Least Dangerous Branch 16-23 (1962); P. Bobait, Constitutional Fate: Theory of the Constitution (1981).

3. See, e.g., R. Berger, Federalism: The Founders' Design (1987); R. Berger, Government by Judictary: The Transformation of the Fourteenth AMENDMENT (1977); W. Graglia, Disaster by Decree: The Supreme Court Decistons on Race and the Schools (1976).

4. See, e.g., Ely, Toward a Representation-Reinforcing Model of Judicial Review, $37 \mathrm{MD} . \mathrm{L}$. Rev. 451 (1978); J. Ely, Democracy and Distrust (1980).

5. Ackerman, The Storrs Lectures: Discovering the Constitution, 93 YAlE. L.J. 1013, 1030, 1044-51 (1984); cf. Wellington, The Nature of Judicial Review, 91 YALE L.J. 486 (1982) (discussing the non-final quality of judicial review). 
strikes a responsive cord in many lawyers and legal academics, myself very much included, in part because it replicates some of the aspirational features of the adjudicative process itself- "neutral" decisionmaking, principled deliberation, and dialogue.

In this symposium and elsewhere, the "republican revival" is being debated on a variety of theoretical grounds: whether it sufficiently protects those "natural rights" implicit in liberal theory; whether reasoned deliberation will lead to objectively agreed upon values; and whether the particular vision articulated by modern civic republicans finds support in American or constitutional history. This essay focuses on a somewhat more practical issue: whether, given the state of twentieth-century American political institutions, the republican ideal of deliberative decisionmaking may be in tension with other republican goals, such as equality, participation, reflective innovation, and universalism. Ironically, the academic literature on political parties suggests that the general approach outlined by Sunstein (and others) for promoting reasoned dialogue in our political institutions may have the potential for undermining public political participation, especially among poorer groups; increasing irrationality in public programs; and protecting the status quo. Indeed, institutional changes in Congress over the last thirty years, which provide a useful case study of some elements of the civic virtue strategy, support this prediction. To the degree that this is true, the civic republican pursuit of rational dialogue may be attractive, but of uncertain value in furthering these other republican goals.

\section{The Givic Republican Philosophy}

Givic republican writers are faced with a fundamental dilemma. As most lawyers recognize, political institutions are populated with many private regarding representatives, lobbied by narrow self-interested organizations, and elected by many citizens concerned primarily with their personal welfare. ${ }^{6}$ In light of this political and social culture, the question then becomes how a system can be structured so as to stimulate reasoned dialogue-the linchpin of the civic republican's pursuit of universalism, participation, reflective innovation, and equality? In the absence of a real world decisionmaking device analogous to a Rawlsian veil of ignorance,

6. A rich literature has detailed the effectiveness of various interest groups in influencing legislative behavior. See Stigler, The Theory of Economic Regulation, 2 BELL J. ECON. \& MGMT. ScI. 3, 3 (1971); Peltzman, Constituent Interest and Congressional Voting, 27 J.L. \& EcoN. 181, 210 (1984); Peltzman, Toward a More General Theory of Regulation, 19 J.L. \& EcoN. 211, 213 (1976); Posner, Theories of Economic Regulation, 5 BELL J. ECON. \& MGMT. Scr. 335, 335-36 (1974).

More recently, however, a variety of scholars have questioned the pervasiveness of this phenomenon, documenting numerous instances of so-called public-regarding activity by legislative actors. See, e.g., M. Derthwick \& P. Quirk, The Politics of Deregulation 252-58 (1985); D. Robyn, Braking the Special Interests 1-11 (1987); S. Kelman, Making Public Policy 231-47 (1987); A. MaAss, Congress and The Common Good, 3-31 (1983). 
Sunstein discusses several doctrines which he believes will promote modern civic republicanism. ${ }^{7}$ A brief review of a few of these devices is helpful in illuminating what I understand to be the underlying theory behind this approach.

\section{A. Civic Republican Constitutional Doctrines}

In general, the most important structural goal appears to be political insulation: "Madisonian republicanism calls for substantial autonomy on the part of representatives." As noted here and in Sunstein's earlier Stanford article, representatives' relative insulation from "pressure" by their constituents helps free them to deliberate in the public interest. ${ }^{\theta}$ The apparent assumption is that "the people" are less likely to possess virtue than their representatives; unreflective representation of popular will and interests would thus be unlikely to further a deliberative democracy. At the creation of the republic, various structural devices, such as representative democracy itself and indirect election of the Senate and President, helped to further this goal. ${ }^{10}$ While it is unclear what further structural changes, sponsored by the court or constitutional amendment, would be offered by modern civic republicans to protect or extend this original conception, civic republicanism appears to be sympathetic to this type of approach. ${ }^{11}$

One device which Sunstein does discuss here for enhancing independence and stimulating dialogue is strengthened judicial review of legislative deliberations, which hopefully would help ensure that legislators do not reflexively follow their constituents' or lobbyists' interests, and consequently that a full debate occurs. ${ }^{12}$ While heightened judicial review of the legislative process, like the hard look doctrine from which it derives historical and intellectual support, ${ }^{13}$ is unlikely to excise self-interest from legislative motivations, the presumption appears to be that such review

7. I review these techniques not to debate the nuances of the legal standards-which I presume will undergo further development as civic republicans continue to explore "institutional arrangements and doctrinal shifts . . . that might serve to implement the most attractive features of the republican vision," Sunstein, Bejond The Republican Revival, 97 YALE L.J. 1539, 1541 (1988)-but to illuminate what I take to be the underlying theory and approach for furthering this dialogic vision.

8. Id. at 1560.

9. Id.

10. Id. at 1560-61.

11. See, e.g., Farber \& Frickey, The Jurisprudence of Public Choice, 65 Tex L. Rev. 873, 912 n.224 (1987); Elliot, Constitutional Conventions and the Deficit, 1985 DukE L.J. 1077, 1104-10 (arguing for reforms to the structure of Congress such as a twelve year term without the possibility of reclection.).

12. Sunstein, supra note 7, at 1579 .

13. See Motor Vehicle Mfrs. Ass'n v. State Farm Mut. Auto Ins. Co., 463 U.S. 29, 48 (1983). For favorable analyses of these efforts, see, e.g., Bruff, Legislative Formality and Administrative Rationality, 63 TEx. L. REv. 207, 237-40 (1984); Sunstein, Deregulation and the Hard Look Doctrine, 1983 SuP. Cr. REv. 177, 179, 181-84, 206-13. 
would create added incentives for legislators to engage in principled deliberations.

Of course, the extent and nature of this dialogical mandate is somewhat unclear. Legislators and legislative bodies act for a variety of motivations and reasons. Presumably, however, some reasonable number of members would need to have engaged in a rational debate to satisfy the deliberative ideal. Dialogue presumes that there is an exchange of views, an obligation by decisionmakers to explain decisions and answer the criticisms by challengers. ${ }^{14}$ As Sunstein explains, republican theories "require public regarding justifications offered after multiple points of view have been consulted and (to the extent possible) genuinely understood."15 In order to stimulate such exchanges, judicial review would need to be greatly strengthened. ${ }^{16}$

Another method Sunstein advocates for promoting the dialogic ideal is proportional representation of different groups' interests within the legislative body. Sunstein describes this requirement as a second best solution to the difficulties in creating a true Madisonian dialogue among legislators who often will be psychologically bound by their homogenous life experiences. ${ }^{17}$ Proportional representation helps ensure that a rich diversity of viewpoints will be heard and considered. ${ }^{18}$

Taken together, the discussions of proportional representation, insulation, and enhanced judicial review all reflect what I take to be the basic civic republican philosophy for promoting public regarding dialogue among political actors. The underlying goal of civic republicans, as articulated by Sunstein, is to create a diverse government of relatively "insulated" and "autonomous" political actors. Checks and balances, federalism, and bicameralism are more familiar constitutional elements of this general principle - that by placing authority in the hands of independent actors and institutions, each participant will be forced to understand and

14. See, e.g., B. Ackerman, Social Justice in the Liberal State 4 (1980) (in "Neutral" dialogue, "[w]henever anybody questions the legitimacy of another's power, the power holder must respond not by suppressing the questioner, but by giving a reason that explains why he is more entitled to the resource than the questioner is"); Fiss, The Supreme Court, 1978 Term-Foreword: The Forms of Justice, 93 HARv. L. REv. 1, 13 (1979) (in judicial dialogue, judges are obligated to listen and respond).

15. Sunstein, supra note 7 , at 1575.

16. Sunstein does not specifically advocate a constitutional requirement of legislative due process, although that presumably would help ensure that "multiple perspectives" are presented during legislative deliberations. Indeed, a legislative body subject to judicial review of its motivational goals might well choose to supplement legislative procedures as a means of discharging this constitutional requirement. For a discussion of this issue, see Farber \& Frickey, supra note 11, at 920-24; Linde, Due Process of Lawmaking, 55 NEB. L. REv. 197, 235-55 (1976).

17. Sunstein, supra note 7 , at 1588.

18. As Sunstein acknowledges, proportional representation appears to reduce insulation of political actors. To this extent, it might work at cross purposes with the goal of political insulation, see Comment, Politics and Purpose: Hide and Seek in the Gerrymandering Thicket after Davis v. Bandemer, 136 U. PA. L. REv. 183, 213 (1987), although it would serve to increase the diversity of any dialogue or debate that ultimately ensued. 
deliberate with others in order to secure government action, thereby promoting reasoned dialogue. As Hamilton observed: "The oftener [a law] is brought under examination [and] the greater the diversity in the situations of those who are to examine it, the less must be the danger of those errors which flow from want of due deliberation, or of those missteps which proceed from the contagion of some common passion or interest." ${ }^{\text {"19 }}$ Sunstein echoes this view: "[T]he systems of checks and balances, bicameralism, and federalism responded to the central republican understanding that disagreement can be a creative force," an "indispensable part of the basic republican faith in political dialogue."20

\section{B. The Value of Dialogue in Furthering Other Social Goals}

Although valued as an end in itself, the resulting deliberative dialogue is also associated with other beneficial effects. Since every major viewpoint will be assured "a piece of the action," political participation and social equality should be furthered. At the same time, the normative and rational failings of pluralism-its supposed bias toward elite and wealthier groups and against diffuse interests-may be overcome, or at least reduced, through rational deliberation. Moreover, because a true dialogue presumes that arguments will be listened to and answered, there is less likely to be a bias towards the status quo: every program is open to challenge and rational debate, and perhaps reformulation. ${ }^{21}$ Thus, rational dialogue is supposed to lead to, or be associated with, greater equality, participation, innovation, and universality.

\section{The Social Impact of the Givic Republican Reforms}

\section{A. Civic Republicanism and Division of Power}

In evaluating these arguments, it is important to recognize at the outset that the likely result (if not goal) of the republican approach is a dispersion of power within the political process. As a theoretical matter, rational dialogue, if it is to be taken seriously, inherently presumes an equalization of influence, especially as compared to a centralized structure of a strong president or party leaders. Ideally, each political actor is to be engaged, consulted and understood, that is, treated as an end. He cannot be ignored or merely directed to adhere to a party line in return for party favors or out of concern for central party discipline. ${ }^{22}$

19. The Federalist No. 73, at 443 (A. Hamilton) (C. Rossiter ed. 1961).

20. Sunstein, supra note 7 , at $1562,1575$.

21. Id. at $1557,1566-71,1581$.

22. This phenomenon seems implicit in Sunstein's description of rational dialogue, in which multiple points of view must be "consulted" and "understood". Other descriptions of rational dialogue by legal scholars seem consistent with this perspective. See B. ACKERMan, supra note 14, at 4 (1980) (rational dialogue requires that political actors engage in a conversation); Fiss, supra note 14, at 13 (judicial dialogue requires that all arguments be answered); Mashaw, Administrative Due Process: 
As a practical matter, moreover, political actors who are "autonomous" and "insulated" from constituent pressures (a primary goal of civic republicanism) will indeed be more independent politically-free to defy and challenge party or national leaders who cannot hold them accountable through resort to popular pressure. Historically, party leaders and presidents have been able to secure cooperation from congressmen by virtue of their ability to replace recalcitrant politicians at re-election time, their power to withhold party campaign funding, patronage, and support, and the knowledge of congressmen or political supportors that their electoral fate is tied to the political and administrative success of the general party or president. ${ }^{23}$ In contrast, civic republicanism ultimately relies on a leader's ability to secure cooperation through dialogue.

Finally, the stated purpose of proportional representation, one of Sunstein's specific recommendations, is to disperse authority directly by giving each group "a piece of the action." Sunstein describes the goal of this and other civic republican proposals as "multiplying the points of access to goverment" and "generat[ing] institutions that will produce deliberation among those differently situated." This dispersion, it is hoped, serves to ensure a rich diversity of viewpoints in government, and thus a full and developed rational dialogue. ${ }^{24}$

\section{B. Political Party Perspective}

Unfortunately, there is a serious cost to the republican approach, a cost which can be illustrated by contrasting it with the more traditional political science reaction to some of the same concerns of inequality, declining political participation, bias towards the status quo, and special interest group influence. This political science solution, which has the "strong[] support" of "a large majority of mainstream political scientists in the field," is not pluralism, but strong political parties. ${ }^{25}$ As I have argued in greater detail elsewhere, ${ }^{26}$ and summarize only briefly here, political parties serve to centralize authority, creating large scale institutions that at-

The Quest For a Dignitary Theory, 61 B.U.L. Rev. 885, 899-901 (1981); Michelman, The Supreme Court, 1985 Term-Foreword: Traces of Self-Government, 100 HARv. L. REv. 4, 33 (1986).

23. See, e.g., M. Fiorina, Retrospective Voting in AMErican Elections 209 (1981); Ferejohn \& Fiorina, Incumbency and Realignment in Congressional Elections, in The NEw DIRECTIONS IN AMERICAN Politics 91, 93 (J. Chubb \& P. Peterson eds. 1985).

24. See Sunstein, supra note 7, at $1585-89$. To be sure, on one level, the use of courts to engineer these reforms might be viewed as centralizing power in that branch, at least over the short run. In addition, Sunstein's proposals on statutory construction, which often envision the courts independently imposing their own deliberative judgments, have no direct effect on dispersion within the political branches. See Fitts, The Vices of Virtue: A Political Party Perspective on Civic Virtue Reforms of the Legislative Process, 136 U. PA. L. REv. 1567, 1591-92 n.77 (1988) (discussing court centered approaches to civic virtue). As I understand it, however, the underlying theory behind the civic republican approach to reform of the political branches favors a dispersion of influence among political actors as a means of stimulating dialogue.

25. L. Sabato, The Party's Just Begun 2 (1988).

26. See Fitts, supra note 24. 
tract diffuse majority support and overcome some of the collective action problems in popular political organization as well as government administration. The result is the "generation of countervailing collective power on behalf of the many who are individually powerless against the relatively few who are individually-or organizationally-powerful."27

The way political parties achieve these goals, however, is very different from the civic republican approach. According to the political science literature, insulation of individual government actors and dispersion of government power is a serious problem in government, both as an impediment to effective and coordinated action and as a system that facilitates the influence and power of concentrated and wealthier special interest groups. Political parties, which seek to overcome those discrete sources of influence, are thus "the special form of political organization adapted to the mobilization of the majority."28

Not surprisingly, the political party literature views political dialogue and ideological politics, especially in the extreme, more skeptically. According to Sunstein, modern civic republicanism envisions rational dialogue as a "Rawlsian ideal" - by leading participants to "think from the point of view of everyone," a type of consensus is often achieved. ${ }^{28}$ Much of the political science literature suggests, however, that ideological debate-discussing public problems in terms of fundamental questions and beliefs-can sometimes create and exacerbate divisions and disputes in a public political context. ${ }^{30}$ Deep moral discussion can thus undermine the ability to reach consensus, and take action.

Many political scientists also point out, on the other hand, that particularistic incentives and pragmatic political coalitions-the antithesis of ideological debate-can foster beneficial public policy. Patronage, as well as other particularistic devices, can be powerful tools for mobilizing support and centralizing political authority across dispersed political institutions, thereby enhancing majority rule and the effectiveness and consistency of administration. In general, party compromise, although unable to invoke the lofty principles of reasoned discourse, frequently allows deals to be

27. W. Burnham, Critical Elections and The Mainsprings of American Politics 133 (1970).

28. E. Schattschneider, Party Government 208 (1942); see also A. Ranney, The Doctrine of Responsible Party Government 11 (1962); E. Schattschneider, The Semi-SoverIGN People 78-96 (1960).

29. Sunstein, supra note 7 , at 1554-55.

30. See Orren, The Changing Styles of American Party Politics, in The Future of AMERIGAN Political Parties 25, 30 (J. Fleishman ed. 1982); J. Wilson, The Amateur Democrat: Club Politics in Three Ciries 358 (1962); A. Wildavsky, The Goldwater Phenomenon: Purists, Politicians, and the Two Party System, in The Revolt Against THe Masses 246, 257-69 (1971). As Stephen Holmes writes: "In a liberal social order, the basic narrative framework must be able to command the loyalty of individuals and groups with widely differing self-understandings and conceptions of personal fulfillment. As a result, theorists of justice can achieve their principal aim only by steering clear of irresolvable metaphysical disputes." Holmes, Gag Rules or The Politics of Omission, in Constitutionalism and Democracy (J. Elster \& R. Slagstad eds. 1988). 
reached-"giving to each group some but never all of what it wants."31 While constitutional decisions and popular attitudes have reduced the extent of this activity, especially at the federal level, self-interest politics and party campaign funding remain important devices at times for enabling political leaders to mobilize the public, centralize authority, and coordinate action. ${ }^{32}$

\section{G. The Civic Republican Reforms}

In light of this more sympathic view towards the value of centralization and particularistic incentives, what is the likely result of the civic republican approach in terms of the social ideals Sunstein sets forth-namely, greater innovation, universalism, participation, and equality? I am somewhat pessimistic.

First, many of the changes Sunstein discusses may well serve to protect the status quo. As he recognizes, some of the proposals would create impediments to government taking action-in the public choice vernacular, collective action problems. Proportional representation, insulation of individual legislators, and supplementation of checks and balances are intended not only to offer each group a foothold, but if rational dialogue is to be taken seriously, a foothold with influence. In purpose and effect, these reforms, especially proportional representation and public funding of political campaigns, tend to accelerate the decline of political parties as centralizing institutions, increasing the dispersal of authority, both within Congress and between Congress and other institutions. ${ }^{33}$ As a result, there might well be a corresponding decline in the ability of government to act consistently and expeditiously, leading to greater political gridlock.

To a proponent of civic virtue, this insulation of decisionmakers and dispersal of authority create a fundamental problem: They bias the political system in favor of the status quo, or at least in favor of private market solutions to social problems. Although Madison himself might expect and welcome this result-that was one original rationale for checks and bal-

31. A. Ranney \& W. Kendall, Democracy and the American Party System 508 (1956).

32. Indeed, paradoxically, pork barrel politics-the antithesis of civic republicanism-also can be an important device (perhaps the most important device) for offering legislators the independence civic republicanism presumes. Historically, legislators' ability to bring home local projects and perform constituency services has permitted them to perform legislative activities free of constituent control. Pork barrel politics can thus help solve one of the dilemmas of civic republicanism-how to secure for representatives the independence to engage in reasoned dialogue when they are faced with a citizenry animated by self-interest. See Fitts, supra note 24 , at 1632-33.

33. For a discussion of the decline of political parties, and its consequences, see W. CroTTY, american Parties in Decline 275-79 (1984); N. Nie, S. Verba \& J. Petrocik, The Changing American Voter 73 (1979); D. Price, Bringing Back the Parties 105-07 (1984); Burnham, American Politics in the 1970's: Beyond Party?, in American Party Systems: Stages of Polttical Development 308, 340 (W. Chambers \& W. Burnham eds. 2d ed. 1975). Of course, public funding of campaigns through centralized parties would not be inconsistent with a political party approach. 
ances throughout our political system ${ }^{34}$-it appears in tension with the modern civic republican rejection of status quo baselines.

Indeed, recent trends in Congress over the last 30 years, during which time control of central party leaders has become more dissipated and individual congressmen far more autonomous and insulated, provide a useful case study of the civic virtue approach. As a result of reduced party identification within the electorate as well as increased constituency servicing and distributive legislation, congressmen now have far greater independence from the President, party leaders, and chamber officials. In the present decentralized congressional environment, which civic republicanism presumably would applaud and seek to accelerate, more groups have been able to find representational expression within the power structure, and ideological political debate also has increased-as civic republicans theory would hope and predict. ${ }^{38}$ On the other hand, there have been serious difficulties with this dispersion, which has accompanied the decline of parties in Congress and across government generally. As the political party scholars predicted, Congress's ability to undertake coordinated action has seriously diminished, frequently leading to political stalemate. ${ }^{36}$

A second related difficulty with the civic republican approach is that the dispersion of political authority may enhance the influence of special interest groups, thereby undermining the consistency and rationality of our overall legislative product, as well as its democratic legitimacy. A system that seeks to or has the consequences of severely dividing power-by promoting proportional representation and political autonomy-is likely to undermine those institutions that tend to support majority rule, and expand the influence of narrow groups to assert their influence. Once again, the historical literature on Congress is instructive. The dispersal of authority in Congress over the last thirty years, as innumerable scholars have demonstrated, has had a profound impact on the influence of narrow specialized constituencies, which are able to obtain a legislative foothold and trade that position for legislative influence. One result is a propensity toward budget deficits and legislation that often serves a variety of inconsistent objectives. ${ }^{37}$

34. See, e.g., The Federalist No. 10, at 82-84 (J. Madison) (C. Rossiter ed. 1961); The Federalist No. 73, at 443-44 (A. Hamilton) (C. Rossiter ed. 1961); see also Easterbrook, Statutes' Domains, 50 U. ChI. L. Rev. 533, 549-50 (1983).

35. See M. DeRTHICk \& P. QUIRK, supra note 6, at 252-58; Wilson, The Politics of Regulation, in The Politics of Regulation 357, 370-72 (J. Wilson ed. 1980); Sinclair, Building Coalitions in Congress, in The New Congress 178, 217-20 (T. Mann \& N. Ornstein eds. 1981).

36. See e.g., B. Cain, J. Ferejohn \& M. Fiorina, The Personal Vote 14, 21 (1987); I. Dodd \& R. SchotT, Congress and the Administrative State (1979); M. Fiorina, ConGRess: Keystone of The Washington Establishment 66, 73 (1977); L. Reiselbach, ConGressional RfForm 88-89 (1986); D. Vogel \& S. Waldman, Congress and Democracy 91-97 (1985).

37. See e.g., B. Cain, J. Ferejohn \& M. Fiorina, supra note 36, at 21; Cogan, The Evolution of Congressional Budget Decisionmaking and the Emergence of Federal Deficits (Standford Working Paper No. P-88-6, 1988); Inman, Federal Assistance and Local Services in the United States: The 
Of course, to the degree that a rich civic republican debate actually ensues, this concern could be somewhat minimized. Groups would sometimes be able to gain influence by the power of their ideas, not their members' organizational influence. Moreover, although the influence of special interest groups may undermine majority rule, there is some question, according to civic republican theory, whether pure democratic rule is itself a coherent or legitimate organizing principle for public decisionmaking.

As the history of the last thirty years suggests, however, it is difficult to believe that a diverse organization such as the United States Congress would be able to achieve a civic republican concensus very often. More importantly, our constitutional system, as Sunstein recognizes, does not adopt any singular approach; majoritarian democratic principles continue to retain a firm hold on constitutional doctrine and academic theory. Indeed, a concern with the counter-majoritarian aspects of interest group pluralism-the disproportionate advantage of narrow self-interested groups-fuels part of the civic republican critique. ${ }^{38}$ Civic republicanism is supposed to ensure that the legitimate objectives of all the public are furthered. To the extent that civic republicanism increases the organizational advantages of narrow constituancies, therefore, it may be subject to the same criticisms it has raised against pluralism.

A final concern with modern civic republicanism-one I find perhaps most troubling -is its possible effect on social equality and political participation. As Sunstein discusses, once civic republicanism focused on furthering its principles in a national government, as distinguished from homogeneous local communities, the problem of creating a governing body infused with republican ideals became exacerbated. ${ }^{39}$ The Madisonian solution, which Sunstein apparently wishes to endorse, is to increase the separation of the elected from the governed and hope to induce a public regarding ideological dialogue among government actors through judicial review and multiplying the points of access of different groups and interests to government.

Unfortunately, the likely effect of this civic republican strategy upon a mass public that still influences policy through democratic election may be counterproductive. In many cases, large segments of the general population, disproportionately drawn from the poor and undereducated, are less able to understand, evaluate, or participate in such elite debates. In other words, "the generally held belief among elites that the public understands political abstractions is an optical illusion, generated by the fact that the elite stratum is consumed in political conversation with itself, and only

Evolution of a New Federal Fiscal Order, in Fiscal Federalism and Quantative Studies (H. Rosen ed. 1988).

38. See Sunstein, supra note 7, at 1545-46; see also Sunstein, Interest Groups in American Public Law, 38 Stan. L. Rev. 29 (1985).

39. See Sunstein, supra note 7, at 1556. 
rarely has occasion to discuss politics with the apolitical man citizenry."100 As a result, "an issue-oriented electorate is one likely to increase the influence of the better educated and upper income groups over electoral decisions."

In addition, the dispersion of political authority implicit in this approach can also increase voter confusion over the responsibility of different representatives for government actions. With multiple decisionmakers and group dialogues, it becomes extremely difficult for voters to understand which political officials are responsible for government programs, and to hold them accountable. Is a President, a party leader, a committee chair, a coalition leader, or simply an individual representative, answerable for government action or inaction in a system with "multiple points of access" and rational dialogue? Though special interest group representatives will probably be able to answer that question, the general public will probably not.

Indeed, one prominent political scientist has suggested that the decline of parties and rise of dispersed ideological politics over the past few years explains the low level of political participation and voting in the United States today, especially among the poor, and indirectly the election by a minority of eligible voters of Ronald Reagan. ${ }^{42}$ If this perspective is taken seriously, the ultimate result of an even more ideological and dispersed debate could well be a more apathetic and alienated public. Rational dialogue and participation would only be an elite phenomenon.

All this is surely not to deny the substantial and insightful contributions Sunstein makes to thinking about these issues. In light of the now recognized weaknesses in democratic theory-both normative and rational-civic republicanism offers an alternative vision of reasoned deliberation that correctly accounts for much of our existing legal structure and maps out various fruitful avenues for potential reform. Clearly, party rule is not the total answer; our political system embodies both democratic and republican principles.

At the same time, modern civic republicanism, at least in my view, has not solved the problems associated with self-interested actors in government. ${ }^{43}$ Even though insulation and multiplying points of access may increase dialogue, in many cases they may also confuse the public, exacerbate divisions, reduce popular political control among the poor, and create

40. W. Neumann, The Paradox of Mass Politics: Knowledge and Opinion in the American Electorate 22 (1986).

41. W. CROTTY, supra note 33, at 276-79; see also Burnham, The Turnout Problem, in ElECtions American Style 97, 132 (A. Reichley ed. 1987); W. Burnham, The Appeatance and Disappearance of the American Voter, in The CurRent CRISIS IN AMERICAN Politics 121, 196 (1986).

42. See Burnham, supra note 41 , at 131 .

43. For some of my own speculations on possible approaches, see Fitts, supra note 24, at 1644-45. See also Fitts, Ignorance Can Be Bliss: Imperfect Information as a Positive Influence in Administrative and Legislative Decisionmaking (working paper). 
a structural bias in favor of the status quo. Rational dialogue is an admirable goal. I wish I could be sure that it will not be pursued at the expense of political equality, participation, and innovation. 